\title{
Linguistic Messianism
}

\author{
Christopher Straud \\ University of the Western Cape/Stockholm University
}

Manuel Guissemo

Eduardo Mondlane University/Stockholm University.

\section{INTRODUCTION}

$\mathrm{M}$ ozambique, like many nations in the geopolitical South, is a country grappling with issues of equity and justice. One of the more pressing issues pertains to the role of language in ensuring citizenship agency and voice. Much of this debate has been concerned with how to envisage the interrelationships and divisions of labor between local languages and Portuguese, that is, the form and organization of multilingualism. Mozambique since independence in 1975, has given increasing recognition to its many languages and to the diversity of its population, rolling out mothertongue programs across the country (albeit experimentally) and recognizing the importance of local languages for plurality and cultural heritage. Nevertheless, Portuguese has remained the official and most significant language since colonial times to the present, and has strengthened its status as the language of modernity, national cohesion and global networking.

The implications of this are many. One consequence that will concern us in this paper is that the meaning, significance and indexical values of African languages vis a vis Portuguese have, in fact, remained remarkably constant from colonial time to the present. This is notwithstanding what at first blush appears to be a radical revaluation of their status and some seismic shifts in the sociopolitics of the nation brought about by independence and increased democratization since the 1990s.

In this paper, we argue that this constancy is not accidental, but a key dimension of how multilingualism as a particular political regime of language organization has been used historically and in contemporary time as a technology of liberal governance. Ahluwalia has said of postcolonial states that they are "first and foremost products of colonialism" (Ahluwalia 2001:71), noting with Ashcroft that "a postcolonial society is a society continually responding in all its myriad ways to the experiences of the colonial contact" (cited in Ahluwalia, 2001: 91). Stark and Brusdt claim that social change can be seen not so much as 'transition from one order to another, but as transformation - rearrangement, reconfigurations, and re-combinations, that yield a new interweaving of the social logics that are a 
modern society" (cited in Pitcher 2004: 7). Thus, despite the majority of postcolonial states at independence replacing structures of colonial patriarchal and paternalistic liberalism with new forms of coexistence, the ideological blueprints of colonial orders across society have remained resiliently in place. We argue here that multilingualism, commonly understood as the co-existence and juxtaposition of more than one language, is one mechanism whereby essential features of colonial social logics are reconfigured in contemporary 'postcolonial' societies. To this end, we interrogate how multilingualism, while ostensibly promising a trope for linguistic (and cultural) diversity, is best seen, in common with other forms of neoliberal governance, as a response to "the effects of anti and postcolonial movements in the liberal world". It does this by "allow/ing/ cultures a space within liberalism without rupturing the core frameworks of figuring experience" (Povinelli, 2011).

Our argument will be that this state of affairs is a direct consequence of particular ideological tropes on language that locate languages (repertoires or speech practices) in different temporal framings and accord them different orders of visibility for purposes of governance. With respect to temporalization, Benjamin is credited with postulating the distinction between 'empty homogenous time' - time moving forward, measured by clock time, an axis /along which/ to link otherwise disparate events" (Eisenlohr, 2004), and 'messianic' time, a "sacred, simultaneity across past, present and future". Irvine (2004: 99) remarks on how "ideologies of temporality are inevitably ideologies of language, with Eisenlohr (2004) noting how /languages/ contribute to the temporal structuring of social worlds by establishing relationships between linguistic forms, communicative practices and sociocultural valuations (Eisenlohr, 2004: 81).
Kerfoot (ftc) offers a notion of 'orders of visibility' by which she means "the hierarchies of objects, social relations, ways of knowing, being and saying concealed or embedded beneath the apparently common sense and taken for granted in policies and practices". 'Orders of visibility' offers a way of capturing the emergence and 'coming-to-prominence and recognition' of different alignments of language temporalities that define different understandings of multilingualism as for particular purposes of governance.

In the Mozambican context, African languages and Portuguese have been framed differently with respect to two broad types of temporality and organized into different orders of visibility. Together these construct a politico-ideological concept of multilingualism that organizes and regiments languages (speech practices, repertoires), and that produces sociocultural valuations of speakers and communities ${ }^{1}$. To the extent that language mediates forms of citizenship, and is the edifice on which national imaginaries are constructed (c.f. the common trope of Mozambique as a Lusophone country with 25 Bantu languages), politico-ideological concepts of multilingualism are one important dimension along which states are organized. Furthermore, a politicoideological multilingualism contributes to the construction of contemporary (postcolonial and independent) Mozambique as a complexly layered, colonial chronotope.

Our analysis of multilingualism in these terms raises a conundrum, namely to what extent - if at all - and under what forms can a politics of language, and forms of language activism that promote local languages specifically, contribute to the bringing about of a new sociopolitical order? Can a promotion of multilingualism built on the edifice of colonial/liberal idea of multilingualism as latticed temporalities arranged in 
regimes of visibility contribute to a blueprint for a decolonial society that breaks with the continuities of the past? And if it proves to be the case that multilingualism is primarily a conduit for the reproduction of a colonial social logic, where do we look for alternatives?

We wish therefore to address three main themes in this paper. Firstly, we wish to complicate our understandings of multilingualism as a complex and diverse 'liberal/colonial' notion (Section 2). Secondly, we hope to demonstrate a continuity - even reproduction - in the linguistic mediation of colonial and postcolonial social logics (Section 3 ); and, thirdly, we wish to interrogate what a potential approach to (linguistic) decoloniality could involve, given the critical analysis of multilingualism that we sketch here (Section 4).

\section{CLEAVAGES AND CONTINUITIES IN COLONIALISM AND POSTCOLONIALISM}

Metropolitan colonial states such as Portugal in the flush of colonization found themselves confronted with a fundamental contradiction. A modern state is founded on a liberal notion of citizenship and a conception of individual rights that recognizes the equality of its citizens and regulates their relationship to the market and the state. However, this was far from the situation in the colonial dominions. Instead, colonial states were predicated "largely on the legalities of exclusion and the politics of difference" (Comaroff, 1998: 343), that was layered into colonial bifurcations between urban-rural, civilizednative, citizen-subject common-lawcustomary-law. The contradiction was compounded by the striving of "colonial regimes seeking to convert 'natives, simultaneously and contradictorially, into both rights-bearing citizens and culturebearing ethnic subjects" (Comaroff, 1998: 344). Colonial Mozambique made sense of this contradiction by replicating it across languages, and then using language policies as a tool to inscribe the contradiction into the machinery of the state in ways that allowed government processes to overcome it.

\subsection{Tempering colonial cleavages}

In order to manage the contradiction, the Portuguese had to imagine the colonial subject as out of step with modernity, and as lost, disorganized, and dislocated from society, although nevertheless able to transcend this condition with some assistance. Linguistic temporalities, conceptions of time through which languages are construed, offered a key ideological tactic in managing the cleavage between a native subject and a metropolitan citizen. Irvine remarks that "visions of historicity, origins, and mutability, ideologies of temporality, /.../ are inevitably ideologies of language" (Irvine, 2004: 99; cf.. also Woolard, 2004). Throughout the colonial moment in Mozambique, African languages and Portuguese have been embedded into different conceptions of time - African languages have been inserted into discourses of historicist time, whereas Portuguese is seen predominantly in messianic terms. This meant that African languages were conceived as languages that underwent (historical) change, that they were languages in flux and that they may have had an original form not necessarily identical to their present incarnations; they were also seen as potentially shifting their shape even more in the future. The ascription of historicity to African languages was essential to colonial governance as it was the means whereby missionary linguists 
could scientifically reconstruct the origin and pristine past of 'tribes' - an important aspect of linguistic tribalization of the landscape and thus also important in the definition of local territory. The Swiss missionary, Henri Junod, for example, believed that "the Thonga language ought to be considered as the oldest element in the life of the tribe" (quoted in Harries, 1995: 163), and that by ridding the language of foreign elements, the original proto-Tsonga would reveal its very ethos (cf. Stroud, 2007).

Identifying the indigene, and situating the colonial subject in a territorial space isomorphic to the higher order category of nation-state, conveniently motivated a form of proxy government by regulos, or tribal Chiefs, who ruled on behalf of colonial government to collect taxes and organize labor (cf. Stroud 2007). The 'tribalization' of the Mozambican linguistic landscape, geographically delimited and 'populated' by 'speakers' of particular languages, also provided a raison d etre for specific cohorts of Christian missionary linguists, each with claims to ownership to their tribe, their language and their particular version of the Christian doctrine (cf. Harries 2010).

The idea that African languages were subject to historical change lent legitimacy to the argument that these languages had long left behind them the purity of the proto-languages, and now existed only in the twilight present of problematic Babelian chatter and morally repugnant diversity. Then, as now, African languages were seen as wild and undisciplined, and in need of pruning and straightening. They were labelled dialectos, ${ }^{2}$ not languages, and said to be as corrupt and inadequate as the speakers, the indigenes, who had deformed them,

In their alleged civilising mission, the Portuguese constructed the
Portuguese language as the language of modernity and civilisation, whereas African languages were conceptualised as inferior forms of speech (pejoratively called 'dialectos'), which should be 'restricted to the informal, home domains and to ideas of tradition and the local' (Stroud, 2007: 30. Cf. also Chimbutane, 2011: 40).

It was this conjuncture of Christian values, the temporalization of African languages in historicist time, and the need for the colonial state to find ideologically effective forms of governance that created the semiotic space for the construal of African language speakers as backward and morally corrupt who could improve their lot through work. The native subject was pegged to governance by Christian concepts of moral good and self-improvement linked to economic imperatives of work and forced labor (Fabian, 1986).

Portuguese, on the other hand, figured, as something that had historically always been the way it is now and will continue to be so in the future. The durative present is simultaneous with its grand history, a history of, and with, the present moment, and a history that is co-occurrent with its glorious future. In contradistinction to the flux and waning of African languages, this messianic sense of Portuguese offered up organizing tropes of stability and national unity, stretching back into history and forward into new transnational spaces. Stories about Portuguese tell of how the linguistic outback was tamed and brought under state control and increasing Christian enlightenment in an unfolding of 'linguistic domestication' and a relentless flow of 'civilization'. Portuguese also made possible an imaginary of the seamless spatial connectivity of Mozambique, Angola and other colonial conquests 
to mainland, metropolitan Portugal as 'overseas departments'. Sousa talks about the spatial concept of 'totality' - that which promotes a homogenous concept of wholeness that produces the invisibility of the diversities' (de Souza, ftc.). Portuguese was an integral part of the geographical imagination of 'Portuguese totality' together with forms of spatial semiotics, such as planted forests and landscaping, architecture and town planning, monuments and tourist guides, that served to etch Portuguese history onto the landscape.

The juxtaposition of these different temporal discourses define a politicoideological notion of multilingualism that played an important part in making sense of the colonial contradiction. It did this not only by mapping ideas of origin, change and futurity differentially onto African languages and Portuguese, thereby providing an epistemological/ ontological framing in support of this politico/religious ordering of coloniality. Equally important was how the multilingualism inscribed and managed this colonial cleavage into the machinery and institutions of the state.

\subsection{Inscribing the contradiction in the organs of the state}

The delicate latticing of African languages in historicist time and Portuguese as messianic provided the technology to manage the liberal contradiction of colonialism and to replicate the colonial order across the various organs of the state and throughout institutional spheres. Multilingualism as a politico-legal notion opened up pathways and opportunities for indigene mobility, change, advancement and citizenship through the acquisition of Portuguese, while simultaneously and strongly re-affirming the colonial binary of subject-citizen by maintaining the association of African languages to historicist time and subjecthood.

Not surprisingly, schooling was one of the institutions that regulated the use of Portuguese and African languages in Catholic and Protestant schools. Although Portuguese was to be used (as the language of the 'civilized'), the fact that the majority of the Mozambican population at that time did not master this language forced the authorities to allow the use of indigenous languages in the teaching of Catholic religion, the sole purpose which was to assure a timely evangelization of the indigene (cf. Mazula, 1995: 66; Firmino, 2010: 7, see also Stroud, 2002: 261; Ferreira \& Viega, 1957)*.

The colonial cleavage between citizen and subject was also managed through legislation around linguistic trajectories. As the indigene was not considered a citizen, but a traditional subject, a set of procedures and requirements were laid out that would allow the 'native' to loosen his shackles and become a citizen of Portugal. Thus, the interrelationships between Portuguese and African languages refers explicitly to "the extinction of the condition of the indigenous and acquisition of citizenship." Besides having to be older than 18 years - and the stipulation that the citizen-to-be should have a profession, art or craft - an

\footnotetext{
* This was accomplished and made operational by the signing into agreement of the Santa Sé a Concordat and the Missionary Statute (cf. Mazula, 1995: 66) The Concordat contained clauses on language pertaining to education, religion and citizenship.
} 
important requirement was to be able to correctly speak the Portuguese language (cf. Ferreira \& Viega, 1957: 112). Multilingualism thus regulated colonial contradictions at the very core of the state apparatus itself - its institutions of schooling, religion and citizenship.

\section{POSTCOLONIAL TEMPORALITIES}

Since independence in 1975, successive waves of political reform have sought to refine a more inclusive notion of citizenship built around the construction of commonality in difference rather than division (Mamdani 1996). It has also sought to create a new national imaginary around a modernist consensus. With regard to both of these issues, politicoideological notions of multilingualism, cut to the same cloth as the earlier colonial constructs, have played a significant role.. The messianic role of Portuguese in uniting the territory was explicitly reaffirmed with the signing of the Lusaka peace agreements between the Portuguese government and the leadership of the main resistance movement, Frelimo. This agreement concluded the armed struggle against the colonial regime in Mozambique on 7 September 1974. Portuguese takes pride of place here as a key unifying factor in an otherwise potentially divisive liberation movement, and is prefigured at this moment as the official language and language of national unity in Mozambique. There is some irony in the fact that the final tribute to colonial modernity and coming-to-age of an independent African Mozambique was marked by the postcolonial adoption of Portuguese as the language of unity and the reaffirmation of African languages as potentially divisive.
Subsequent postcolonial representations of language have very much been about the differential recognition of the sociocultural valuations of speakers and communities linked to different notions of multilingualism. As mentioned, a useful notion with which to capture these shifting scales of recognition is that of order or regime of visibility. Kerfoot (ftc) highlights the similarity of this notion to Foucault's 'orders of discourse' (1981[1970]), 'a kind of gradation among discourses' (Foucault, 1981: 55) and provides a useful paragraph from Weedon (1997: 108) that illustrates nicely the effects of orders of visibility in structuring different forms of multilingualism as

ways of constituting knowledge, together with the social practices, forms of subjectivity and power relations which inhere in such knowledges and relations between them. Discourses are more than ways of thinking and producing meaning. They constitute the 'nature' of the body, unconscious and conscious mind and emotional life of the subjects they seek to govern (Weedon, 1997: 108)

During colonial time, African languages were all but invisible in official spaces, with the notable exception of language maps or in connection with the recruitment of converts to Christian constituencies. Some grudging visibility came out of the granting of the use of African languages as a temporary tool to facilitate the learning of Portuguese, a stepping-stone only to acquiring proficiency in Portuguese.

The teaching to which this article refers will always seek to spread the Portuguese language, but as his instrument, may be allowed the use of native languages (Lei do Indigenato, art. 6 \& 1o in Ferreira \& Viega, 1957: 28). 
In all of these cases, African languages were under 'censorship' - an order of visibility that kept Mozambican languages carefully in abeyance on the margins of official, public life and for specific uses only.

In the 30-years since independence, African languages have been inserted into various orders of visibility. They have been censored, monitored and surveilled and their speakers relegated to the twilight of public spheres in the interest of national unity. They have been declared emergent or made spectacularly visible in the race after the indigenous vote, or in the search for cultural heritage; or they have merely existed as a penumbra to the 'correct' use of Portuguese. In all of these cases, the temporal significance of Mozambican languages has remained stable, - never present and contemporary, always of the past and future - and their relationship with Portuguese constant.

\subsection{Uniting the nation}

In postcolonial Mozambique, just as in colonial Mozambique, African languages dwell either in the past or the future, but never in the present. Any discourse on African languages is wont to remove what is said of the language or how it is said from the moment of enunciation there is a clear dissonance between the 'present' of the enunciation, and the past or the future in which the language is located and to which the statements made are meant to apply.

Historicist discourses of Mozambican languages retain their role in postcolonial time of connecting the community back to its pure and pristine ethnic past. Similarly, they remain conceptualized as the antithesis to Portuguese, paradigm cases of disorder and concreteness, associated with ethnic diversity and tribal division. Not surprisingly, then, immediately after independence, new orders of visibility were accorded African languages. From having been mainly invisible or censored during colonial times, they now became the object of surveillance and monitoring, and their use expressly 'forbidden' on the streets of Mozambican cities - all in the interests of national unity (Stroud, 2007: 40).

Official injunctions to use only Portuguese in public spaces could be found on the streets of Maputo, and a communiqe out of the $5^{\text {th }}$ Congress of Frelimo explicitly condemned the use of local languages in public contexts. According to Firmino:
Pressure was even put on the population in general, in order to enforce the wide use of Portuguese. For example, notices posted in public offices reminded people that it was compulsory to use the official language. In some public meetings the translation of Portuguese to the autochthonous languages was avoided in order to reinforce the importance of Portuguese as an official language and symbol of national unity (Firmino, 2002: 235).

At this time, newspapers were rife with letters to the Editor (e.g. the magazine Tempo 1982) with readers lamenting the use of African languages in city spaces. Public enemies were characterized as bottle toting, fifth columnists, whose language was seeped with a mixture of bad Portuguese and a local African language.

The prohibition of African languages was part of Frelimo's strategy to finally divest the old regulos, the local 'chiefs' appointed by the Portuguese to manage the African population on their behalf, of their power. Frelimo also wanted to quell a general dissatisfaction with its socialist planning among segments of the rural population who were predominantly 
speakers of Mozambican languages. Multilingualism and the specific structuring of Mozambican languages as divisive and tribal was a well oiled technique of governance There is undoubtedly an irony in the fact that the government itself employed the very strategies and rhetorics to dismantle colonialism that colonialism itself had employed to build it, namely to insert African languages in discourses of division and origin.

A somewhat later stance on Mozambican languages located them in a 'linguistic interim', a 'bracketing off' of their use in the present. The then Minister of Education, Graça Machel, for example, on the occasion of the First National Conference on the Teaching of Portuguese in 1979 saw Mozambican languages as predominantly a 'substrate' to enrich Portuguese. This is one order of visibility, the 'phantom' bracketing off of contemporary forms of language, not as a value in themselves but as a bootstrapping tool for access into Portuguese.

A later form of recognition of African languages, located them in a future scenario for an enriched Portuguese. This was put forward in the 1988 opening of the First Seminar on the Standardization of the Spelling of Mozambican Languages ${ }^{3}$, with Graça Machel, the Minister of Education and Culture, saying:

In this field, the mother tongues will enrich the Portuguese language spoken in Mozambique and, side by side, will mould more widely and broadly the multiform expression of our Mozambican personality. (NELIMO 1989: 4, cf. Mazula, 1995: 216).

In the late eighties, another form of emergent visibility to gain traction was the teaching of Mozambican languages as mother tongues in bilingual programs.
Advocates of mother-tongue programs saw this as one way to ensure and build the future prosperity of the languages and their speakers. However, as linguists were quick to point out, using African languages as languages of instruction required that they were sufficiently up to speed with respect to orthographies, vocabulary and registers of modernity. The intellectualization of languages became a priority, a process that defined African languages as having a potential or emergent or in spe visibility. At the 1988 conference, an academic research unit at UEM was formed, NELIMO (the Nucleus for the Study of Mozambican Languages), the brief of which was to
research the national languages with a view to /their/ promotion, valorisation, development, /and to /prepare and publish grammars, dictionaries and articles on different aspects of national languages in regards to their structure, function and utilization in society (Sitoe and Ngunga, 2000 quoted by Macaringue, 2014).

Recently, the author Ba Ka Khosa has reiterated a future claim on African languages when he says

\begin{abstract}
We must give citizenship to traditional languages. Each traditional language must have own citizenship to advance. This process requires a very large investment. It has already started and we are going there, but it is still needed maybe two or three generations (cf. Ba Ka Khosa, 2011).
\end{abstract}

The immediate effect of these moves is, of course, to contain the contemporary heterogeneity, diversity and disorder of the languages. Intellectualization removes these languages from the chaos of the durative present. As we saw, characteristically, talking about African languages is always temporally dissonant with the durative 
present, where Mozambican languages appear as weakly visible visitations. In this case, the orders of visibility of African languages are as languages of the future languages to be tilled and cultivated at a later date when the work of intellectualization had been completed.

\subsection{Politics of cultural heritage}

Progress was also formulated as 'plurality'. 1982 marked the beginning of the sole governing party, Frelimo's, embracement of more liberal stance towards cultural heritage, and the recognition of cultural diversity as national wealth, a move that opened up for a more organized approach to the study of Mozambican languages (Mazula, 1995: 215). A new era in the history of Mozambique was thus inaugurated in which the value of African languages in the Mozambican sociocultural landscape was given some form of 'extended' recognition. In today's more constitutional, and more plural Mozambique, African languages have an emblematic visibility (a visibility of display/enactment) as items of cultural heritage.

In the run up to the first democratic election in 1994, the policy of valorization of local African languages gained even more ground. In the new Constitution of the Republic (2004), we read that

the State values the national languages as cultural and educational heritage and promotes its development and growing utilization as vehicular languages of our identity and in Mozambique Portuguese is the official language (cf. Macaringue, 2014: 110).

Cultural heritage then is a particular mix of historical temporality with an emblematic order of visibility.

The author $\mathrm{Ba} \mathrm{Ka}$ Khosa speaks for many when he refers to the need to retake authentic African experiences by connecting back to 'better forms of mother tongues' so that speakers of these languages (in the future, our addition) will have firm cultural footing. Contemporary forms of popular culture in African languages such as Hip Hop are celebrated less for the messages of social transgression in the present that they carry, and more for how they link back to past African art forms and their presumed role in encouraging young Mozambicans to want to use African languages in the future (cf. DeLirio, 2010).

Today, among the middle-class, Mozambican elite, the learning of a Mozambican language often means 'displacing' children from the modern, urban environment, and figuratively transporting them back in time and space to the houses of grandparents in rural areas for a concentrated vacation of language learning (personal communication). This again witnesses to a sense of the historicity, and the perception that authentic and accessible versions of Mozambican languages are literally embodied in the past.

\subsection{Politics and pluralism}

In 1990 Frelimo introduced a new Constitution that allowed multiparty elections, freedom of the media and the right to strike. In July the same year the government and the resistance guerrilla, Renamo, initiated the Rome talks that culminated in the signing of the peace agreement in October 1992, also in Rome. Two years later, in October 1994 the first multiparty election was held in Mozambique (cf. Cruz e Silva s/d). Although the status of Portuguese as the official language of Mozambique and as a factor in national unification was reaffirmed (Stroud, 1999:353), African languages began 
to make a greater appearance in the political arena, where African languages, together with Mozambican culture in general, come to be seen as fundamental and indispensable elements in the construction of the Mozambican state.

In the realm of contemporary formal politics, the move towards decentralization, and in particular, the advent of a multiparty politics, has contributed to the increasing political importance of local African languages in official arenas. The 'indigenes' have become an important political market, still identifiable through the languages they speak, just as with the territorialisation or tribalization of labor force during colonialism. Although now, the orginary temporal discourse associated with African languages is inserted into another regime of visibility, the 'yet-to-appear',

Therefore, the political climate in Mozambique is favourable for the promotion and upgrading of local languages and associated cultural practices (Chimbutane, 2011: 46).

Election campaigns are now also conducted in local African languages, and linguistic virtuosity in mastering many local languages has become an important resource in political display (Stroud, 2007: 43).

In 1994, during the election campaign, African languages were usedfor political mobilization. It was a strategy used by politicians to gain potential voters without proper domain of the Portuguese and at the same time, build a populist image. In the past, politicians moved away from the use of African languages. In the urban public speech, the use of African languages was seen as an indication of tribalism or regionalism, or even conservatism (cf. Firmino, 2002: 107-110).
The current age of plurality on which politicians wish to capitalize has generated a prominent order of visibility, that of spectacle. This is a highly marked and iconized performance of local languages by canvassing politicians, who demonstrate their expert linguistic performance in an ongoing vernacularization of politics.

\subsection{Multilingualism as a colonial trope}

We have suggested that the different values and the differential functionalities of African languages and Portuguese in relation to 'progress' and plurality intersects with the way these different languages are inserted into discourses of temporality and orders of visibility.

Speaking about an African language is always situated in some context of the nonpresent, irrespective of whether this nonpresent is in terms of historical authenticity or in future scenarios of (national) unity in (linguistic) diversity. When Mozambican languages are talked about in the present, they tend to be construed - more or less explicitly - as practices cut loose from a 'real language', as debased and chaotic, or as the empty gestures of languages lost and in need of revival and/or intellectualization. Generally, coloniality inscribed African languages with temporalities of 'originary' 'before', 'anterior', 'traditional', 'outside', 'disordered', 'local', and 'open to change'; and Portuguese as messianic, durative, future-past-present, unchanging/unchangeable. These temporalities helped make sense of colonial management and colonial institutions, and were significant in justifying and perpetuating the colonial bifurcation between disempowered subject and enlightened, privileged citizen. After independence, this very same politicoideological construct of multilingualism as a latticed temporality of African languages and Portuguese has remained a resource 
- for the censorship and containment of ethnic division, for the promotion of a new concept of inclusive citizenship; to a recognition of cultural heritage and new forms of inclusive political voice (vernacularization of political discourse); to 'utopian' imaginings of a future of intellectualized African languages. This took place against a backdrop of a messianic Portuguese that remains unchanging and that retains the links of Mozambique to Portugal and modernity.

The way in which multilingualism in African languages and Portuguese is structured, or conceptualized, along two different temporal narratives (historical and messianist) is a particular way of constraining the form that diversity can take. Orders of visibility extend these temporalities into sociocultural evaluations of speakers and nationhoods. In all of this, multilingualism is a key technology of diversity management in that it filtrates, sifts, and layers languages and speakers.

\section{Governing diversity: The limits of a politics of affirmation}

Multilingualism is a particular way of constraining and containing diversity - a linguistic response to the crisis of postcolonial and anti-colonial movement - to accord recognition to subaltern groups in a way that legitimates the continued hegemony of colonial governmentality (cf. Povinelli, 2011). The politicoideological notion of multilingualism as latticed temporalities reflects the complex history of colonialism - and its continuity in contemporary time. Conditions and parameters for postcolonial governance were put in place in the colonial state itself, and today's technologies of managing a plural state such as Mozambique are basically colonial re-contextualizations (or better re-entextualizations). In this way, multilingualism has been modeled as a technology that fits seamlessly with the functioning of the state as 'discourse', "in the interconnections of governmentality, materiality, modernity and legality" (Comaroff, 1998: 40). In the context of colonial Mozambique, these temporalizations of language built the modernity of colony. In present day Mozambique, notions of temporality and visibility through which African languages and Portuguese have been figured are part of the narrative of modernity and progress. ${ }^{4}$

Given the prevalent discourses that see increased recognition of African languages as a guarantor of democracy and participation, what would the implications of the argument developed here hold for the future of such a politics? Many researchers and educationalists have made the claim that mother tongue education and the officialization or recognition of indigenous languages would 'make a difference' in a myriad ways - from rectifying historical cognitive injustices by facilitating epistemic access to creating the context for greater social cohesion amongst culturally and linguistically different people. The arguments advanced make reference to the cultural values of languages for educational advantage and cognitive justice. Related arguments underscore how local languages may provide the epistemological diversity necessary for the survival of a diverse world. However, the temporal discourses and orders of visibility that lend themselves well to language activists and policy makers who challenge linguistic privilege are cut to the same cloth as those that oppress. Does such a state of affairs not pose a conundrum for policy makers and activists whose very discourse thus risks undermining the political project of local language empowerment to which 
they are committed? Can this 'politics of recognition' really herald a new distribution of visibility and sayability"? Can a politico-ideological notion of multilingualism based in such a politics be part of fundamental socioeconomic and political change?

The French philosopher Ranciere distinguishes between two modes of political functioning, police and politics, and two modes of 'visibility or audibility', phonos (noise) and logos (voice). Policing is business as usual, a politics of the unremarkable and of the everyday, where structures are reproduced in an orderly fashion and everybody knows their place. Voices that do not fit are phonos, mere noise, rabble rousing, terrorism, the cackle of the dispossessed and outlawed. A true politics changes the conditions of play through events that allow the participation of voices previously heard as noise - politics permits or eases the way for other subjectivities to appear, or for already 'recognized' subjects to appear differently. Language politics in Mozambique (and many other countries) are fundamentally policing and guarantors of the status quo. The form in which the acknowledgement of minority/ vernacular languages is construed, is one of a variety of forms of recognition' (from erasure of certain characteristics, to censorship to surveillance, to 'partial recognition') rather than 'appearance'.

Given this scenario, it is hardly unlikely that extant multilingual regimes in postcolonial contexts such as the Mozambican can actually lead to any fundamental redistribution of power, increased participation, societal integration or a more equitable sharing of social, economic or material capital. Neither is likely that the pursuit of multilingual education under current political circumstances will allow for new forms of visibility of previously disadvantaged minorities, or to greater 'sayability' of messages earlier ignored, or clearer 'audibility' of voices previously unheard? Extant policies and practices of multilingualism, education and politics do not appear to be a resource with which to enlarge the potential for all to live differently and otherwise, quite simply because multilingualism, as we conventionally think of it, is a technology of liberal governance that contains expression and constrains participation.

What would seem to be needed is to work on the 'becoming of the present' where speakers and their languages are mined for the resources they offer now. These resources may not be easily recognized as intellectualized standard language prototypes, or linguistic bastions of cultural authenticity. Sousa (2004) has remarked how the future as "the locus of success, development, progress, harmony" is a consequence of a lack of attention to the "complexities, diversities and heterogeneities of the present" (Kerfoot, $\mathrm{ftc})$. We require neither a future based in the past nor a past fleeing from the present, but a project of linguistic decoloniality that rests on the deconstruction of linguistic temproalization and the discourses and epistemologies that support it. We require, in other words, a different politics of a multilingual present, one in which, in Povinelli's terms, ensures how 'a part that has no part gets a part'.

\section{CONGLUSION}

Multilingualism juggles the interplay of temporalities, contributing to the workings of colonial and postcolonial Mozambique by organizing power and difference in ways that make intelligible continuities of colonial/ postcolonial social formations (Povinelli, 2011). Multilingualism in Mozambique (and elsewhere) has always been one 
of a broad range of disciplinary and regulatory practices (Comaroff, 1998:32) deployed by the state in pursuit of its "fabrication of an entire space-time world - and the insinuation of its logic into the mundane practices of human beings-ascitizens" (ibid: 329). One implication of this analysis is that it spurs us to rethink language ontology in explicitly political and decolonial terms.

\section{ENDNOTES}

1 We wish to emphasize at the outset that 'multilingualism is a complex and invested notion in serious need of deconstruction. It is not unusual for a cognitive notion of multilingualism to be used to argue for a political-educational order of languages; or for a political arrangement of languages to motivate a cognitive -learning arrangement of multilingualism (e.g. separation of languages; one person-one language). Although these notions are interlinked, and invite fascinating research to untangle, they are not the same notion.

2 Also as 'languages of the dogs', an interesting enlightenment twist relevant to the dehumanizing of the Other

3 I Seminário sobre a Padronização da Ortografia de Línguas Moçambicanas

4 Povinelli (2011) has coined the term 'social tense' to refer to how difference is managed, as social divisions of time in ways that "help shape how social belonging, abandonment and endurance are enunciated and experienced within late liberalism".

\section{REFERENCES}

Ahluwalia, Pal. 2001. Politics and Postcolonial Theory. African Inflections. London and New York: Routledge.

Ba Ka Khosa, Ungulani. 2011. Cidadania às línguas africanas: conversa com

Ungulani Ba Ka Khosa. < http://www. berlinda.org/BERLINDA.ORG/Pessoas/
Eintrage/2011/8/3_Cidadania_as linguas_africanas_conversa_com Ungulani_Ba_Ka_Khosa.html>

Chimbutane, Feliciano. 2015. Línguas e educação em Moçambique: uma perspectiva sócio-histórica. In Gonçalves, P. \& Chimbutane, F. (orgs). Multilinguismo e Multiculturalismo em Moçambique: em Direção a uma Coerência entre Discurso e Prática. Maputo: Alcance Editores. 35-75.

Chimbutane, Feliciano. 2011. Rethinking Bilingual Education in Postcolonial Contexts. United Kingdom: Multilingual Matters.

Comaroff, John. 1998. Reflections on the colonial state in South Africa and elsewhere. Factions, fragments, facts and fictions. Social Identities 4(3): 321-61

Cruz e Silva, Teresa. (s/d). Moçambique: Um perfil. < http://www.ces.uc.pt/emancipa/ gen/mozambique.html>

DeLírio, Magus. 2010. Uma abordagem sobre a Afrocentricidade do Hip Hop moçambicano. <http://magusdelirio. blogspot.se/2010/12/uma-abordagemsobre-afrocentricidade-no.html>

De Souza, Lynn. (ftc). Epistemic diversity, lazy reason and ethical translation in post-colonial contexts: The case of indigenous educational policy in Brazil. In C. Kerfoot, and K. Hyltenstam (eds.). Entangled discourses: South-North Orders of Visibility. New York: Routledge.

Eisenlohr, Patrick. 2004. Temporalities of community: Ancestral language, pilgrimage and diasporic belonging in Mauritius. Journal of Linguistic Anthropology, 14(1): 88-98.

Fabian, Johannes. 1986. Language and Colonial Power. Berkeley and Los Angeles: University of California Press.

Ferreira, José e Viega, Vasco. 1957. Estatuto dos Indígenas Portugueses das Províncias da Guiné, Angola e Moçambique. Lisboa: SL.

Firmino. Gregório. 2002. A "Questão Linguística" na África Pós-Colonial: O caso do Português e das Línguas Autóctones em Moçambique. Maputo: Promédia.

Firmino, Gregório. 2010. A Situação do Português no Contexto Multilingue de Moçambique. <http://www.fflch.usp.br/ dlcv/lpot/pdf/mes/06.pdf>

Foucault, Michel. 1981. The order of discourse. In R. Young (ed). Untying the 
Text: A Poststructural Anthology. Boston : Routledge. 48-78.

Gomes, P. 2004. O que é uma concordata? $<$ http://www.ucp.pt/site/resources/ documents/ISDC/O q_e co...>

Gonçalves, Perpétua. 2010. $\bar{A}$ génese do Português de Moçambique. Lisboa: INCM

Grosz, Elizabeth. 2011. Becoming Undone: Darwinian Reflections of Life, Politics and Art. Durham and London: Duke University Press.

Harries, Patrick. 1995. The historical origin of standard Tsonga in Southern Africa. In R. Mesthrie (ed). Language and Social History: Studies in South African Sociolinguistics. Cape Town and Johannesburg: David Phillip. 154-75.

Harries, Patrick. 2010. Butterflies and Barbarians: Swiss Missionaries and Systems of Knowledge in South-East Africa. Athens: Ohio University Press, 2007.

Irvine, Judith. 2004. Say when: Temporalities in language ideology. Journal of Linguistic Anthropology, 14(1): 99-109.

Kerfoot, Caroline. (ftc). Introduction . In C. Kerfoot, and K. Hyltenstam (eds.). Entangled discourses: South-North Orders of Visibility. New York: Routledge.

Macaringue, Ilídio. 2014. Política Linguística e Nacionalização do Português de Moçambique. Foz do Iguaçu: Epígrafe.

Mamdani, Mahmood. 1996. Citizen and Subject: Contemporary Africa and the Legacy of Late Colonialism. Princeton, NJ: Princeton University Press.

Mazula, Brazão. 1995. Educação, cultura e ideologia em Moçambique: 1975-1985. Porto: Edições Afrontamento.

Pitcher, M. Anne. 2004. Transforming Mozambique: the Politics of Privatization, 1975-2000. Cambridge: CUP.

Povinelli, Elizabeth. 2011. Economies of Abandonment: Social Belonging and Endurance in Late Liberalism. Duke University Press. Duke University Press, 20

Rosário, Lourenço. 2015. A Língua Portuguesa como Factor de Desenvolvimento Nacional e Afirmação Internacional - Que Desafios?. In Gonçalves, P. \& Chimbutane, F. (orgs). Multilinguismo e Multiculturalismo em
Moçambique: em Direcção a uma Coerência entre Discurso e Prática. Maputo: Alcance Editores. 23 - 34.

Rosário, Lourenço. 1993. Língua Portuguesa e expressão moçambicana. Discursos: Estudos de língua e literatura Portuguesa, Coimbra 3. 109-120.

Sousa, Boaventura. 2014. Epistemologies of the South. Justice against Epistemicide. London and New York: Routledge

Stroud, Christopher. 2009. Towards a postliberal theory of citizenship. In International Perspectives on Bilingual Education: Policy, Practice and Controversy, edited by John Petrovic. New York: Information Age Publishing. 191-218.

Stroud, Christopher. 2007. Bilingualism: colonialism and postcolonialism. In Heller, M. (ed.) Bilingualism: a social approach. Basingstoke: Palgrave Macmillan. 25-49.

Stroud, Christopher. 2002. Framing Bourdieu socioculturally: Alternative forms of linguistic legitimacy in postcolonial Mozambique, Multilingua 21 (2002): 247-273.

Stroud, Christopher. 2001. African mother tongue programs and the politics of language: Linguistic citizenship versus linguistic human rights. Journal of Multilingual and Multicultural Development, 22(4): 339-355

Stroud, Christopher. 1999. Portuguese as ideology and politics in Mozambique: Semiotic (re)constructions of a postcolony. In Blommaert, J. (ed.) Language Ideological Debates. Berlin: Mouton de Gruyter. 343-380.

Weedon, Chris. 1997. Feminist Practice and Poststructuralist Theory. Oxford: Blackwell

Williams, Quentin and Stroud, Christopher. 2013. Multilingualism in transformative spaces: Contact and conviviality. Language Policy (2013)12: 289-311

Williams, Quentin and Stroud, Christopher. 2015. Linguistic citizenship: Language and politics in postnational modernities. Journal of Language and Politics, 14(3): 406-430.

Woolard, Kathryn. 2004. Is the past a foreign country: Time, language origins and the nation in modern Spain. Journal of Linguistic Anthropology, 14(1): 57-80. 